\title{
Nanoparticles in the environment: assessment using the causal diagram approach
}

\author{
Suchi Smita ${ }^{1 \dagger}$, Shailendra K Gupta ${ }^{2 \dagger}$, Alena Bartonova ${ }^{3}$, Maria Dusinska ${ }^{3,4}$, Arno C Gutleb ${ }^{5}$, Qamar Rahman ${ }^{1 * \dagger}$ \\ From HENVINET (Health and Environment Network) final conference \\ Brussels, Belgium. 14 April 2010 - 15 April 2010
}

\begin{abstract}
Nanoparticles (NPs) cause concern for health and safety as their impact on the environment and humans is not known. Relatively few studies have investigated the toxicological and environmental effects of exposure to naturally occurring NPs (NNPs) and man-made or engineered NPs (ENPs) that are known to have a wide variety of effects once taken up into an organism.

A review of recent knowledge (between 2000-2010) on NP sources, and their behaviour, exposure and effects on the environment and humans was performed. An integrated approach was used to comprise available scientific information within an interdisciplinary logical framework, to identify knowledge gaps and to describe environment and health linkages for NNPs and ENPS.

The causal diagram has been developed as a method to handle the complexity of issues on NP safety, from their exposure to the effects on the environment and health. It gives an overview of available scientific information starting with common sources of NPs and their interactions with various environmental processes that may pose threats to both human health and the environment. Effects of NNPs on dust cloud formation and decrease in sunlight intensity were found to be important environmental changes with direct and indirect implication in various human health problems. NNPs and ENPs exposure and their accumulation in biological matrices such as microbiota, plants and humans may result in various adverse effects. The impact of some NPs on human health by ROS generation was found to be one of the major causes to develop various diseases.

A proposed cause-effects diagram for NPs is designed considering both NNPs and ENPs. It represents a valuable information package and user-friendly tool for various stakeholders including students, researchers and policy makers, to better understand and communicate on issues related to NPs.
\end{abstract}

\section{Background}

Within HENVINET, an FP6 funded project, causal diagrams were developed as a tool to evaluate areas of agreement and disagreement between scientists and to identify gaps of knowledge [1,2]. The method of expert elicitation was applied by the HENVINET consortium to assess the health and policy implications of phthalates, where all details in the methodology behind the results presented here of the decaBDE and HBCD elicitations can be found [2]. In addition, an extensive review of the

\footnotetext{
* Correspondence: qamar_15@sify.com

+ Contributed equally

'Amity University, Lucknow Campus, Viraj Khand 5, Lucknow-226010, U.P. India

Full list of author information is available at the end of the article
}

methodology with an overall discussion and analysis of the outcome for all the priority areas of the HENVINET consortium has been made [3]. Furthermore evaluations on advantages and disadvantages of the expert elicitation methodology have been made by others $[4,5]$. This approach has been chosen as one potential method to handle complex issues that are typically faced by the environment and health community and decisionmakers. The current manuscript describes a proposed cause-effect diagram for nanoparticles (NPs) applicable to both naturally occurring NPs (NNPs) and man-made or engineered NPs (ENPs), and provides a short justification for the inclusion of the proposed elements into the presented cause-effect diagram. However, it has to be
Ciomed Central

() 2012 Smita et al; licensee BioMed Central Ltd. This is an Open Access article distributed under the terms of the Creative Commons Attribution License (http://creativecommons.org/licenses/by/2.0), which permits unrestricted use, distribution, and reproduction in any medium, provided the original work is properly cited. 
noted that the presented cause-effect diagram has not been the topic of an expert- elicitation yet.

At the moment, it is unclear whether the benefits of nanotechnologies outweigh the risks associated with environmental release and exposure to NPs and there are concerns that NPs can also lead to a new class of environmental hazards [6]. Until now, relatively few studies have investigated the toxicological and environmental effects of exposure to NPs and ENPs. However, there is enormous effort at national and at international levels including the OECD and the European Union to investigate the impact of NPs on the environment and health. No clear guidelines exist on how to evaluate and quantify these effects, the provision of systematic information following NPs from releases to effects was requested [7] and furthermore it was argued to apply an integrated approach [8]. NPs differ in size, shape, chemical composition and in many physico-chemical properties. It is therefore crucially important to know which properties may cause adverse health effects [9].

Natural and engineered NPs present in the environment are influenced by a large number of physico-chemical processes and show different behaviour in organisms, soil, and water. The accumulation of engineered NPs (ENPs) has been shown in various organisms and environmental compartments, such as blue and green algae, fish and other aquatic organisms as well as soil and sediments [10-16]. Due to the low number of systematic studies and lack of knowledge on physicochemical properties and behaviour of NPs, these reports show an inconsistent picture of the effect of NPs on various environmental processes and their impact on human health. In the present work, we attempt to describe the elements of a causeeffect diagram as already developed within HENVINET for other environmental hazards and disease complexes $[1,2]$. The diagram for NPs is designed on the basis of current understanding of NPs mediated toxicity reports and review articles already available (Figure 1). These diagrams have been shown to be helpful to evaluate the level of confidence in the current ability of scientists to predict the magnitude of a disease burden that are expected to occur as a result of the release of NPs in the environment [1].

\section{Elements of the NP cause-effect diagram Sources of nanoparticles}

Sources of NPs can be classified as natural or intentional and unintentional anthropogenic activities. NNPs exist in the environment since the beginning of Earth's history and are common and widely distributed throughout the earths' atmosphere, oceans, surface and ground water, soil and even in living organisms. Major natural processes that release NPs in the atmosphere are forest fires, volcanic activities, weathering, formation from clay minerals, soil erosion by wind and water, or dust storms from desert.
Atmospheric dust alone is estimated to contain as much as several million of tons of natural NPs within a year [17]. Naturally occurring ambient NPs are quite heterogeneous in size and can be transported over thousands of kilometres and remain suspended in the air for several days.

Man-made ENPs are unknowingly or purposely released in the environment during various industrial and mechanical processes (Figure 2). These NPs are very heterogeneous in nature and currently it is difficult to measure the impact on human health. The annual release of ENPs into the environment cannot be accurately estimated [6] while production volumes are strongly increasing [18]. The unfiltered exhaust gases from diesel engines contain large quantities of potentially harmful NPs from the incomplete combustion of fuel. In the fireplace at home, fullerenes like buckyballs or buckytubes are formed when wood is burned. In industrial processes, coal, oil, and gas boilers release tons of NPs unintentionally [19].

As a growing and widely applied science, nanotechnology has a global socioeconomic value, with applications ranging from electronics to biomedical uses [20]. With the advancement of industrial processes and nanotechnologies, a large number of ENPs are been manufactured and it is inevitable that during the use of the related products, ENPs are released in the air, water and soil both intentionally and unintentionally.

Because of their small size (less than $100 \mathrm{~nm}$ ) and the very high surface to volume ratio, NPs usually display an enormously elevated reactivity potential. NPs can be assigned to a transitional range between single atoms or molecules and bulk material. The physicochemical features of NPs differ substantially from those of their respective bulk materials. Most of the ENPs are made up of carbon, silicon, metal or metal oxides and are believed to adversely affect the environment and human health directly or indirectly together with naturally occurring NPs [3]. Certain carbon nanotubes can cause the onset of mesothelioma, a type of cancer previously thought to be only associated with asbestos exposure, once inhaled $[4,5,21]$. However, this is not caused by the fact that nanotubes have two dimensions smaller than $100 \mathrm{~nm}$ but because they in fact interact with cells similarly to asbestos [4].

\section{Natural occurrence of NPs in environmental matrices and their effects}

NNPs can serve as a model for ENPs in the environment and naturally occurring mineral NPs. Their behaviour can point out important mechanisms in which NPs can move through environments and affect various environmental systems [22]. Once NPs are released in the environment from either natural or man-made sources, very little is known about their environmental fate. Especially NNPs in the atmosphere have been studied in atmospheric sciences 


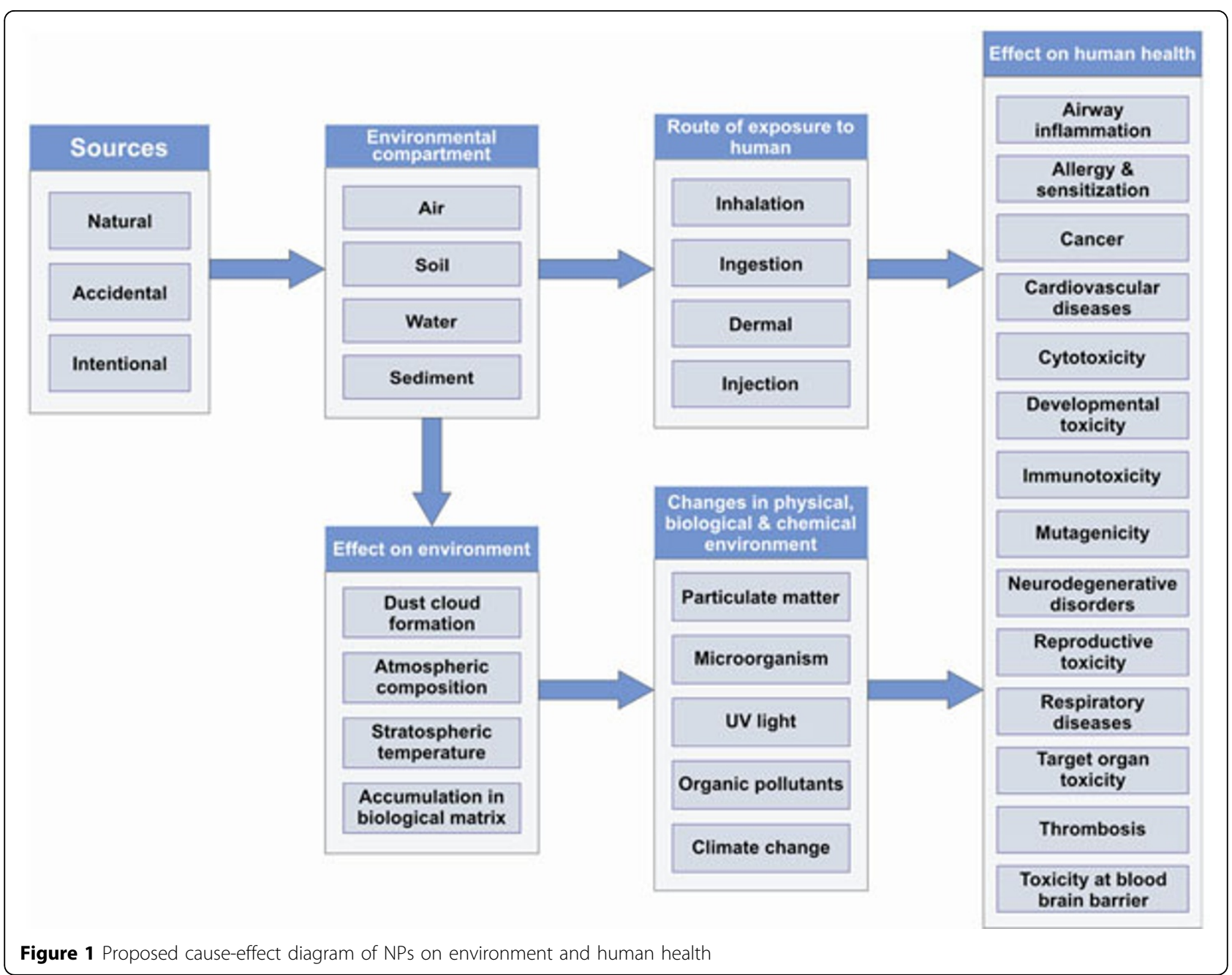

[23]. After release in the environment, NPs will accumulate in various environmental matrices such as air [23], water, soil and sediments including wastewater sludge [24-28].

\section{Effects of NPs on the environment}

Various environmental processes that depend on the presence of physical entities are likely to be altered by the accumulation of NPs in the environment. Some of these processes are dust cloud formation, environmental hydroxyl radical concentration, ozone depletion, or stratospheric temperature change.

Effect of NNPs on dust cloud formation and decrease in sun light intensity

NNPs are thought to play an important role in dustclouds formation after being released into the environment as they coagulate and form dust cloud [29]. 70\% of the brown clouds over South Asia are made up of soot from the burning of biomass; largely wood and animal dung used for cooking and mainly contains particulate matters and carbon NPs from unprocessed fuel [30]. The regional haze, known as atmospheric brown clouds, contributes to glacial melting, reduces sunlight, and helps create extreme weather conditions that impact agricultural production. The pollution clouds also reduced the monsoon season in India $[31,32]$. The weather extremes may also contribute to the reduced production of key crops such as rice, wheat and soybean [29].

\section{Asian brown clouds impact on Himalayan glaciers}

Asian brown clouds carry large amounts of soot and black carbon which are deposited on the glaciers. This could lead to higher absorption of the sun's heat and potentially contributing to the increased melting of glaciers [30]. The Himalayan glaciers provide the source of many of Asia's great rivers, with millions of people depending on them for food and water and because Asian brown clouds increase atmospheric temperature these glaciers have been decreasing over the past decades. 


\section{Sources}

\section{Release of Nanoparticles into environment}

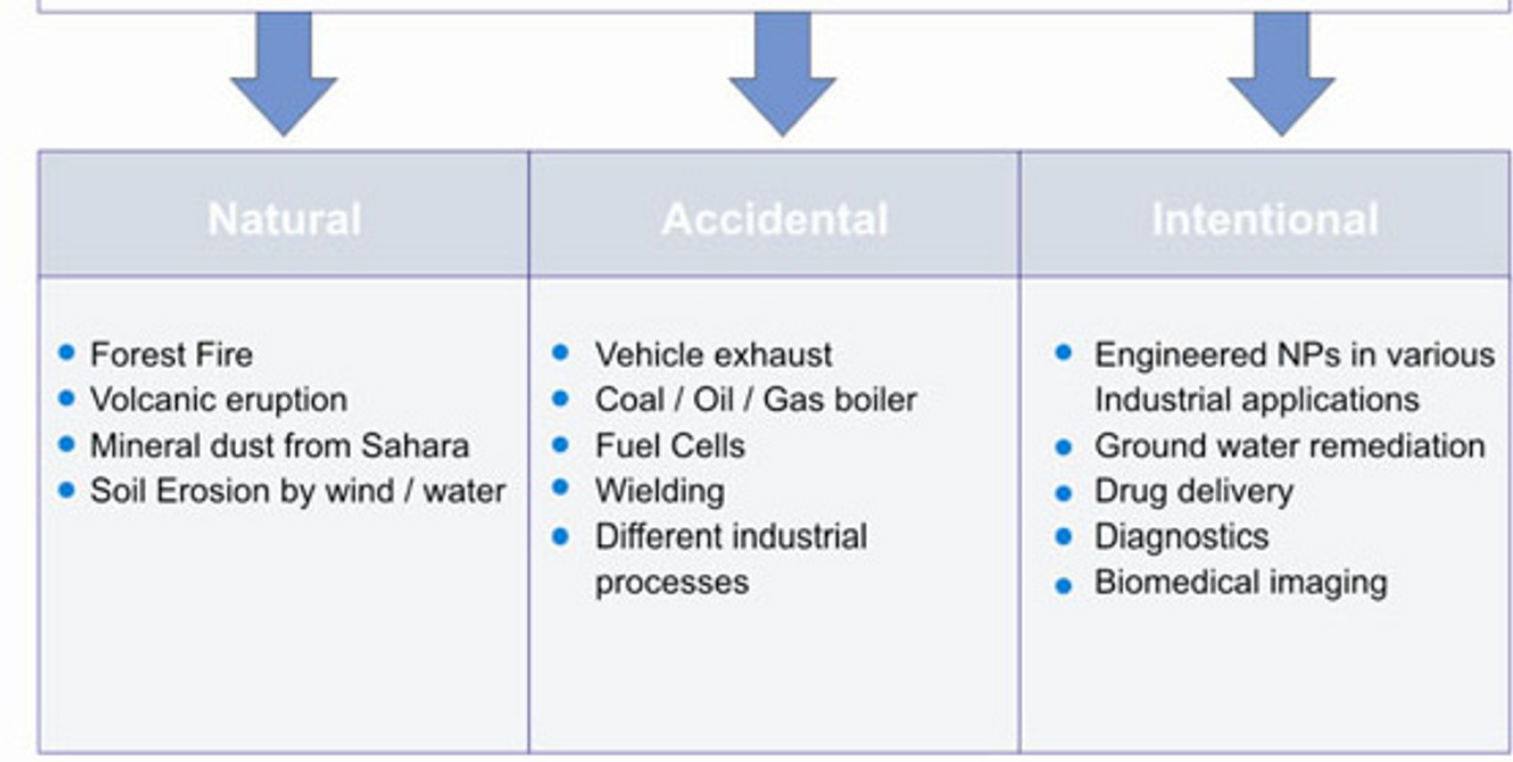

Figure $\mathbf{2}$ Common sources of NPs in the environment.

\section{Asian brown clouds impact on agriculture}

Dimming induced by atmospheric brown clouds is considered the major cause of the changing pattern of rainfall in Asia, with decreasing rainfall in some parts while other parts experience intense floods. Asian brown clouds are interfering with centuries old monsoon patterns with disastrous consequences for food production [29]. The large concentration of ozone in atmospheric brown clouds could decrease crop yields by as much as $20 \%[29,31]$.

\section{Asian brown cloud impact on human health}

A large part of the aerosol particles that make up atmospheric brown clouds are the result of the incomplete combustion of fossil fuels and bio-fuels. This increased exposure to particulate matter also increases the risk of exposure to pathogenic bacteria/ fungi $[33,34]$. The health impact of these particles is an increase in cardiovascular diseases, pulmonary illnesses, fungal/ bacterial diseases and chronic respiratory problems (Figure 3). The report estimates that in India and China alone, Asian brown clouds result in over 330,000 excess deaths per year mainly due to cardiopulmonary diseases [29].

\section{Effect of NNPs on environmental hydroxyl radicals} concentration and ozone depletion in the atmosphere

The hydroxyl radical, which is one of the most reactive free radicals in the environment and plays an important role in the photochemical degradation of natural organic matter and organic pollutants in the environment. NNPs being very reactive immediately bind with hydroxyl radicals and ultimately result in the overall reduction of hydroxyl radicals $[35,36]$. As hydroxyl radicals are strong oxidants and thereby degrading many pollutants, its reduction is responsible for the increase in green house gases, which are ultimately responsible for ozone layer depletion (Figure 4) and cause severe environmental damage [37]. Furthermore it increases the exposure to UV radiation [38], which leads to the increase in incidences of various types of skin cancer in humans.

\section{Effect of NNPs on the decrease of environmental} stratospheric temperature

NPs in the troposphere interact with molecular hydrogen accidentally released from hydrogen fuel cells and other sources $[39,40]$. Molecular hydrogen along with NPs moves up to the stratosphere, resulting in the abundance of water vapour in the stratosphere. This will 


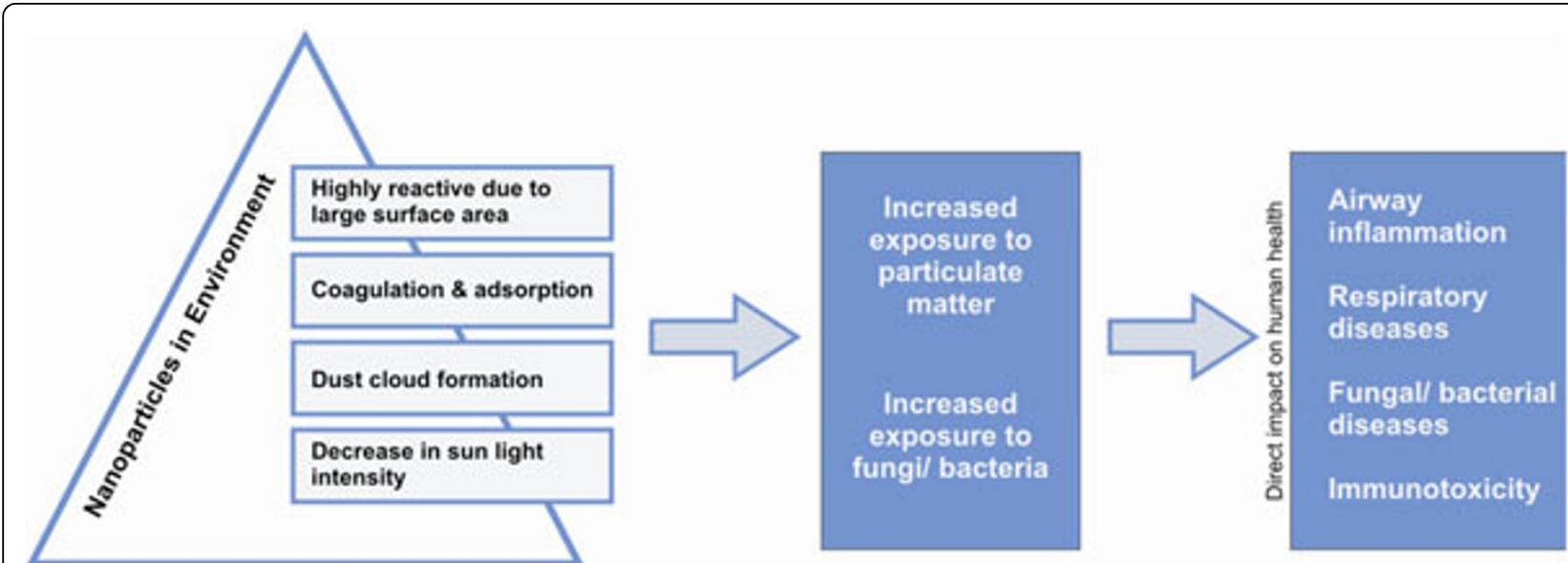

Figure 3 Impact of NPs on dust cloud formation and decrease in sunlight intensity and relation with various human health problems

cause stratospheric cooling, enhancement of the heterogeneous chemistry that destroys ozone, an increase in noctilucent clouds, and changes in tropospheric chemistry and atmosphere-biosphere interactions (Figure 5). Noctilucent clouds are composed of tiny crystals of water ice 40 to $100 \mathrm{~nm}$ in diameter and exist at a height of about 76 to 85 kilometres, higher than any other clouds in Earth's atmosphere. Similar to the more familiar lower altitude clouds, the noctilucent clouds are formed from water collecting on the surface of nano sized dust particles. The sources of both the dust and the water vapour in the upper atmosphere are not known with certainty. The dust is believed to come from micro meteors, although volcanoes and dust from the troposphere are also possibilities. The moisture could be lifted through gaps in the tropopause, as well as forming from the reaction of methane with hydroxyl radicals in the stratosphere. There is evidence that the relatively recent appearance of noctilucent clouds, and their gradual increase, may be linked to climate change [39].

\section{Accumulation of ENPs in selected biological matrices}

It is inevitable that ENPs will be released into the soil and waters during their use and increase the load of ENPs in different environmental matrixes reflected by an increasing concern over the potential impact of ENPs in the environment on aquatic and terrestrial organisms $[6,11,15,41]$. Once released in the environment ENPs may enter plants and other microorganism by active or passive uptake [Figure 6]. NPs absorbed by microorganisms and plants, may enter into the food chain and cause serious alterations in humans and animals [42-44]. NPs due to highly reactive nature and large surface areas have potential to carry toxic materials, such as lipophilic pollutants and heavy metals [45].

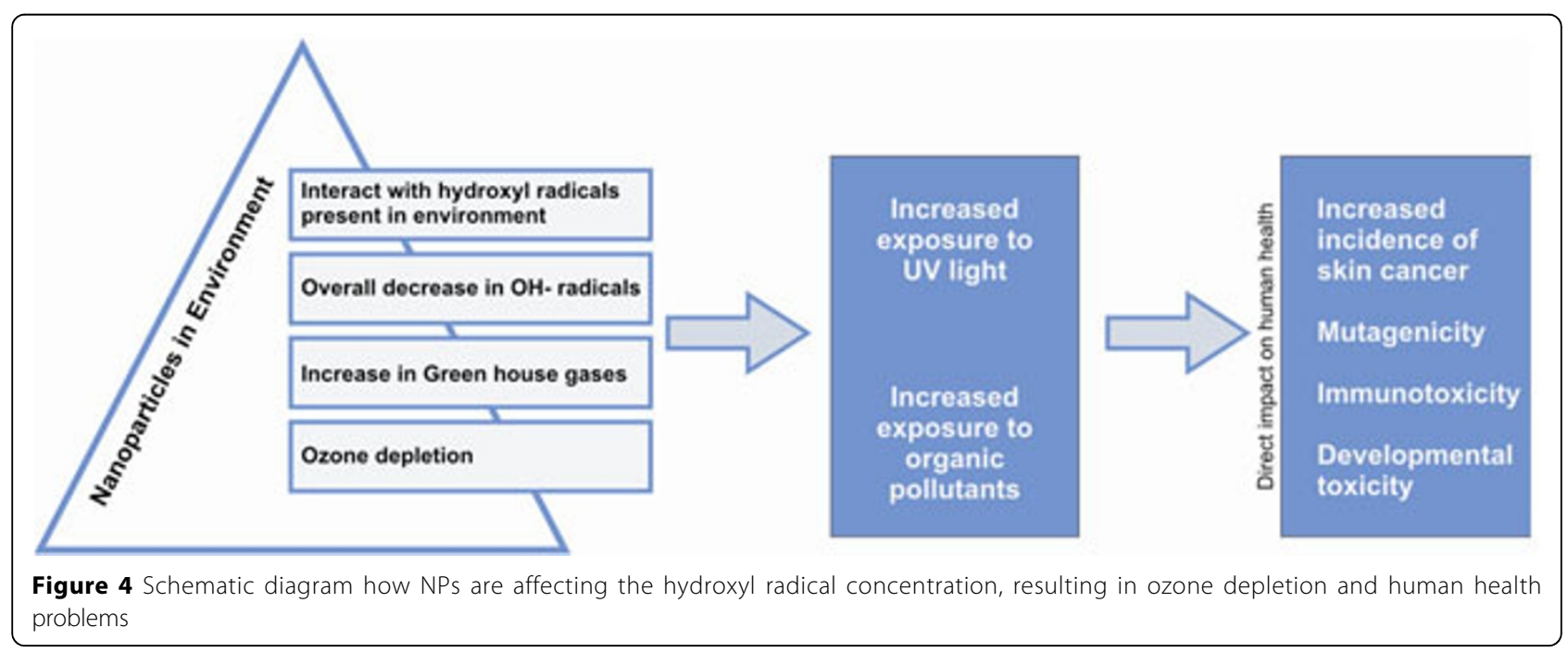




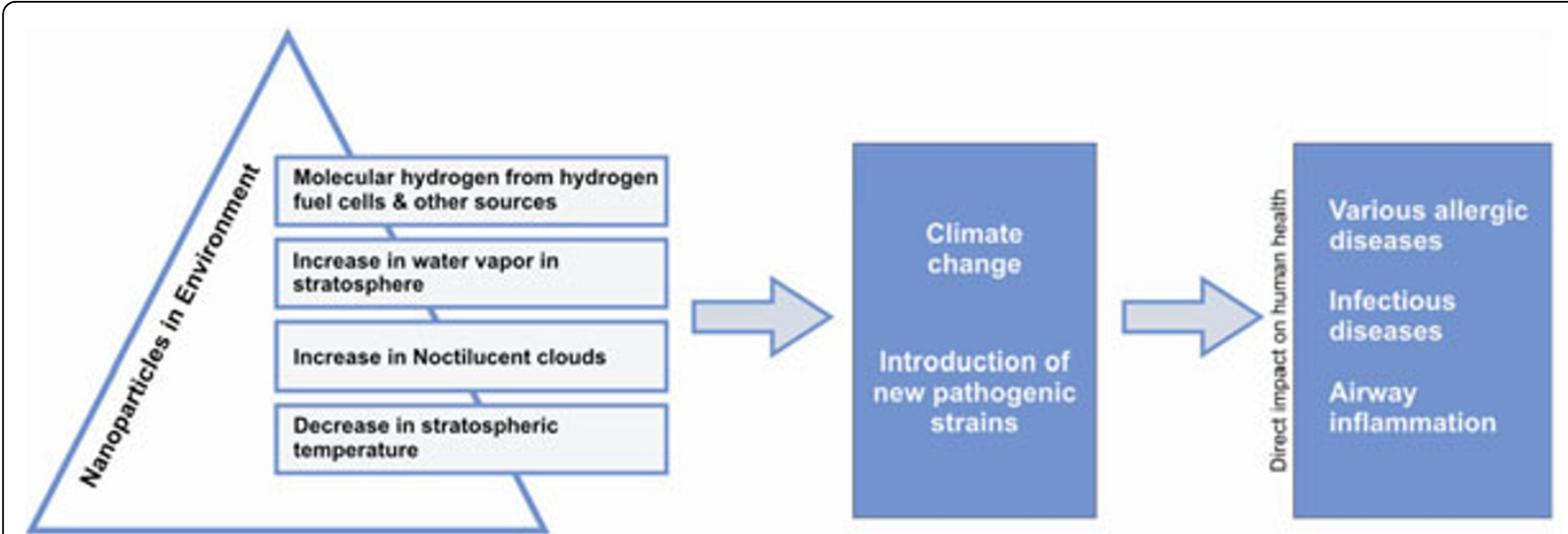

Figure 5 Effect of NPs on the increase in water vapour in stratosphere and decrease in stratospheric temperature resulting in various allergic diseases

Some type of NPs may enter the plants via the root cell walls [Figure 7] [46-48]. Cell walls are semi-permeable and have pores with a size ranging from 5 to 20 $\mathrm{nm}$ that allow the passage of small particles. Thereby NPs and their aggregates with sizes smaller than the pore diameter may pass through the cell wall and reach the plasma membrane. There is some evidence that NPs may enter cells via embedded transport carrier proteins and ion channels and that they may interfere with normal metabolic processes, possibly by the production of reactive oxygen species (ROS) [11]. Airborne NPs accumulate over leaf surface and may enter into the cell through leaf stomata. Thus, plants with a high leaf area and stomatal indices may expect to have the higher interception potential for airborne NPs. Accumulation of NPs on stomatal tissues might alter the gas exchange; resulting in the foliar heating and adverse effects on plant physiology [49]. Carbon nanotubes and aluminium NPs have been identified to inhibit root growth in various economically important plant species by interacting with root surface [50,51]. Carbon black that aggregate on the sperm cells of a marine seaweed (Fucus serratus) were found to reduce the fertilization success rate [52]. Recent reports show the impact of NPs on various food crops. Carbon NPs diminished rice yields and made wheat more vulnerable to other pollutants $[45,53]$, while again it has to be noted that this effect may be due to the asbestos-like behaviour of carbon nanotubes. Thus

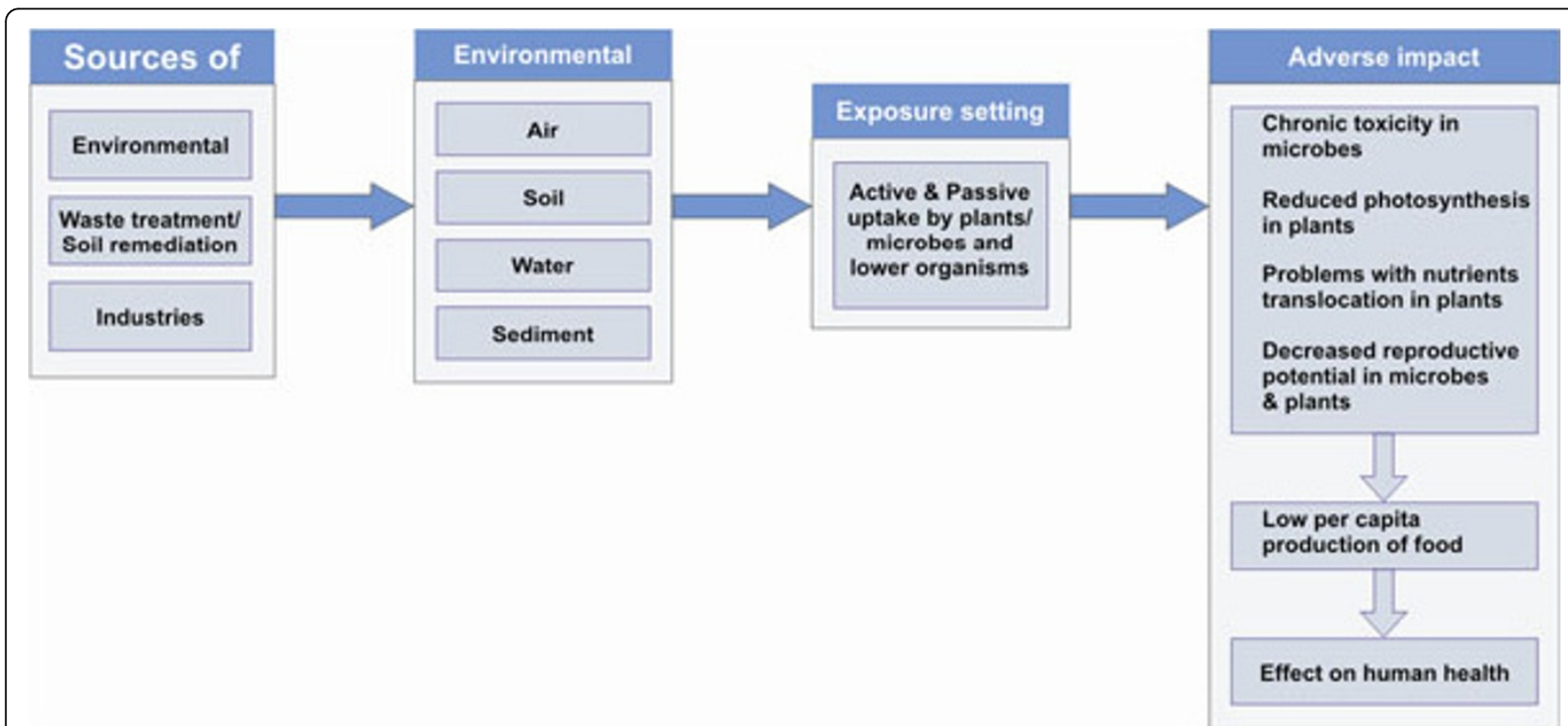

Figure 6 Exposure of NPs to plants, microbes and lower organisms resulting in adverse impact 


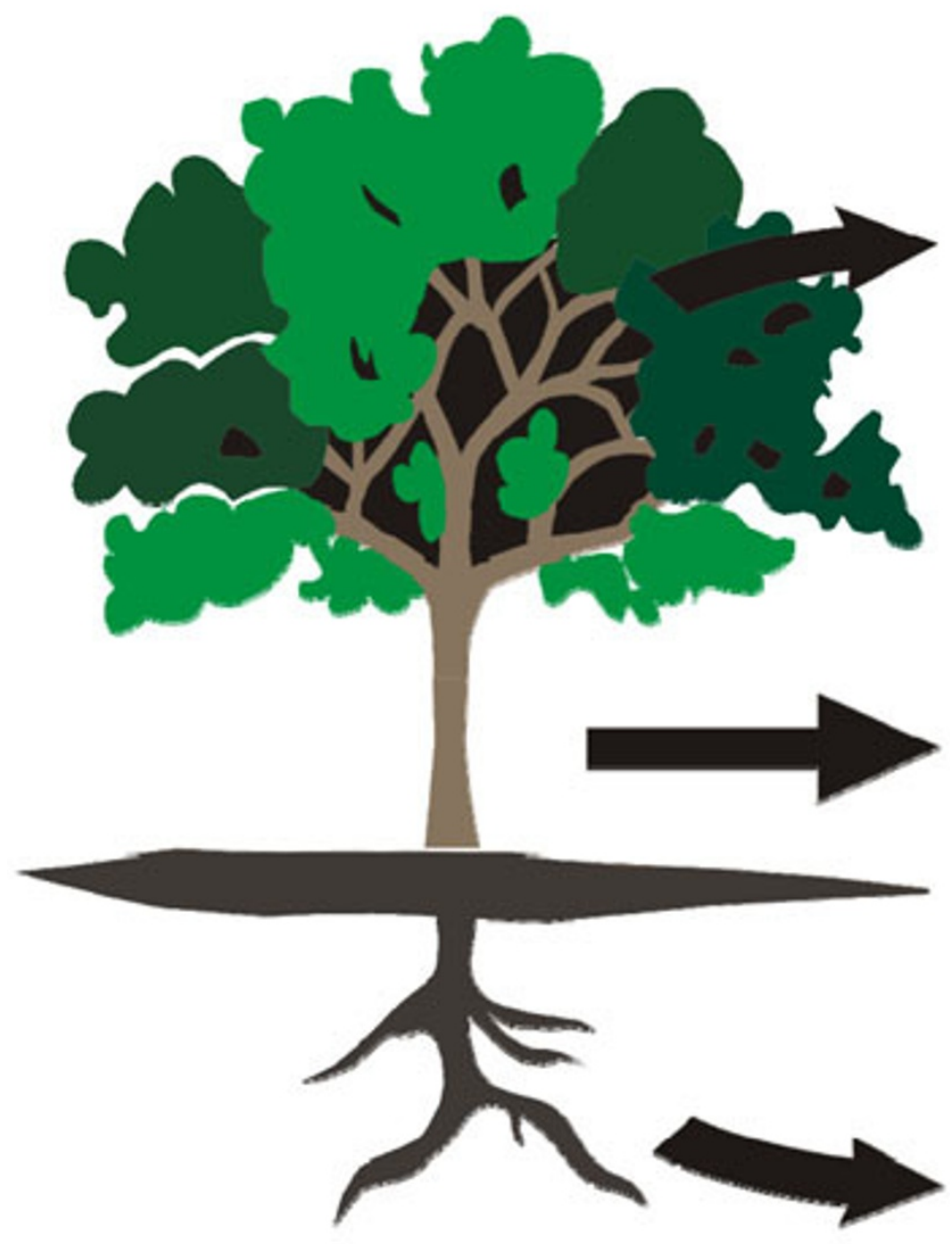

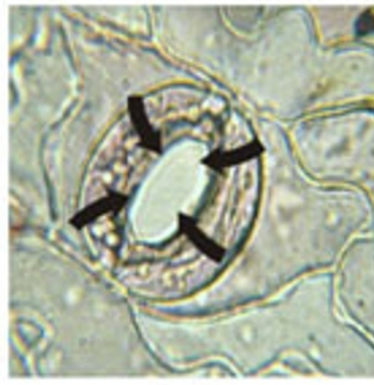

(A)

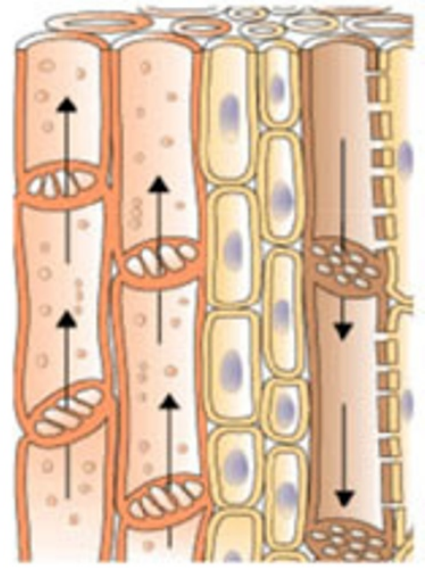

(B)

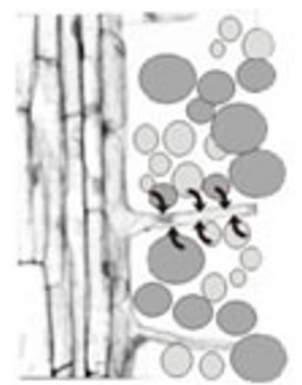

(C)

Figure 7 Effect of NPs on plants NPs may enter into the plants via (A) stomatal cells. NPs entered through stomata may deposit into the cellular system and can affect transpiration, plants respiration, photosynthesis. (B) NPs can deposit on sieve cells and interfere with the translocation of food material and block xylem cells. (C) NPs in soils may enter through the active or passive absorption by root hairs.

NPs are one of the major concerns for a future risk of low per capita food production. The accumulation of NPs on photosynthetic surfaces may cause shading effects, i.e. reduced sun light availability and hence reduced photosynthetic rate.

While the description of the ecotoxicity of NPs is not a central aim of this manuscript NP exposure related effects have been shown for a range of test organisms and NPs. $\mathrm{TiO}_{2}$ NPs were shown to adsorb on algal cell surface, resulting in the increase of cellular weight by more than 2 fold and affecting the algae's ability to float and resulting in reduced sunlight availability for photosynthesis [11]. The toxicity of $\mathrm{TiO}_{2} \mathrm{NPs}$ on green algae Desmodesmus subspicatus has been shown to be size dependent. Smaller NPs $(\sim 25 \mathrm{~nm})$ showed a clear concentration-effect relationship (EC50 of about $40 \mathrm{mg} / \mathrm{L}$ ), whereas the large particles $(\sim 100 \mathrm{~nm})$ were found to be less toxic [10]. Silver NPs exerted considerable toxicity 
in a nematode (Caenorhabditis elegans), especially decreasing the reproduction potential and increased enzyme induction and protein formation [54] but have been shown to also affect a range of other organisms too [55]. NPs may impair the function or reproductive cycles of earthworms, which play a key role in nutrient cycling [56] hence possessing a hazard to induce ecological imbalances.

\section{Human exposure to nanoparticles}

Exposure of humans to NPs mainly occur through natural routes (oral, pulmonary or skin uptake). Exposure assessment is difficult but necessary [8,57-59]. Furthermore many intentional processes such as medical applications may directly inject ENPs into the human body. Under practical conditions the most important routes of uptake for ENPs are inhalation or oral uptake [7], but this has not been specifically studied. More information is available for accidentally released NPs from combustion engines especially diesel exhaust $[60,61]$. In case of aerosolized silver-containing NPs that are widely used in consumer products due to their antimicrobial properties, environmental and human health risk were reviewed in detail [62]. NPs come in the direct contact with skin as they are widely used in various cosmetics and personal care products, and hence the assessment of toxicity due to dermal route of exposure is very critical [6][63][64]. While NPs are already present in food products such as ketchup, intake of NPs through food is another area where exposure assessment is crucial but very little information available on population exposures through ingestion [65]. To facilitate the toxicity assessment of NPs exposure to human, the establishment of exposure registries were recommended to enable the conduct of large-scale prospective multi-center epidemiologic studies [66].

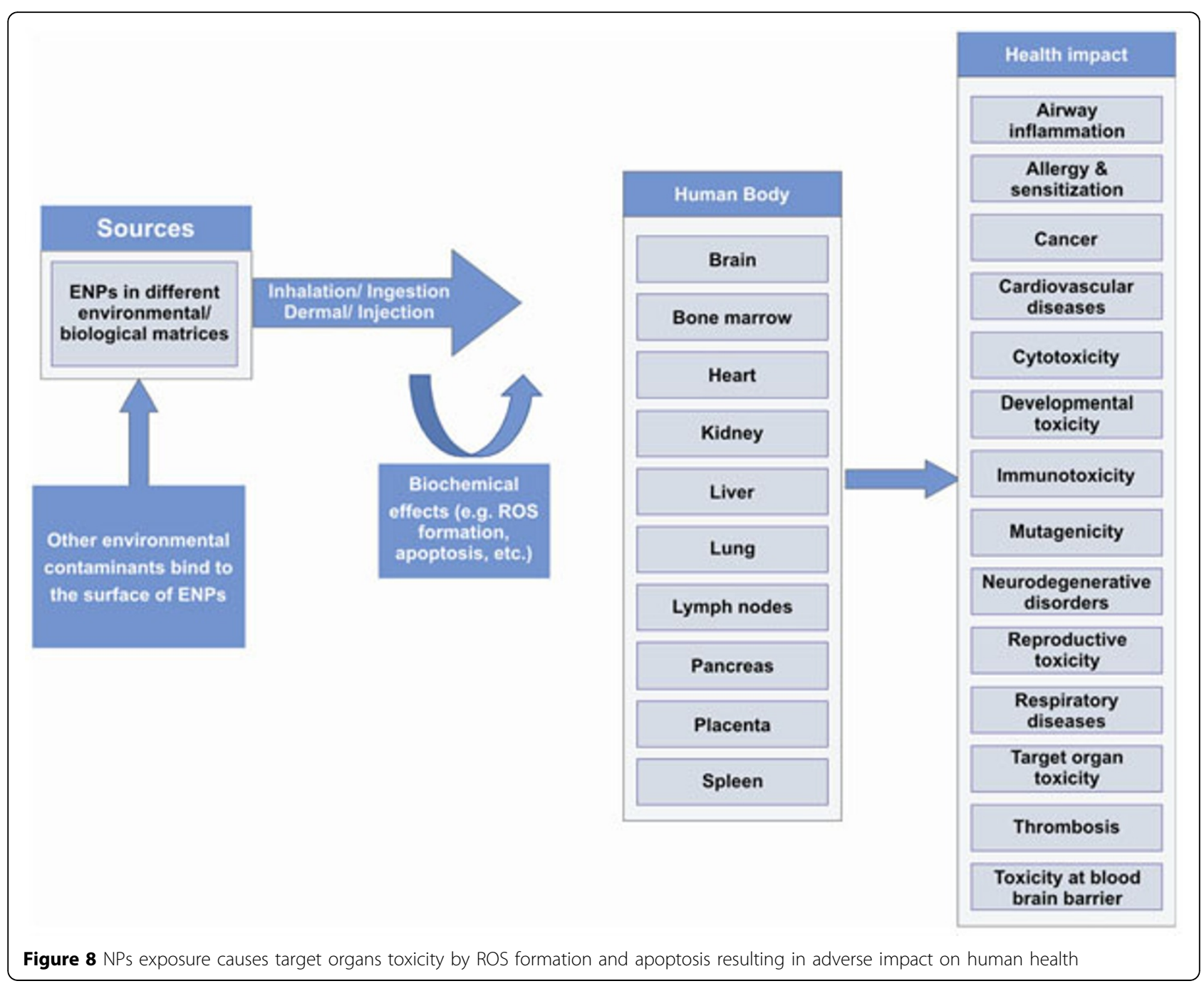




\section{Human health impact of nanoparticles}

Change in the physical, biological and chemical component of the environment directly influences human health. Among them aggregation, agglomeration, dispersability, size, solubility, surface area, surface charge and surface chemistry/ composition have been identified to be most important parameters [9]. A number of potential health effects have been identified probably being related to the exposure of humans to ENPs (Figure 8).

Inhaled NPs are likely to evade phagocytosis, penetrate lung tissue, reaching interstitial spaces and enter blood circulation [67-69]. In the cardiovascular system platelet aggregation, and enhanced vascular thrombosis were observed [70]. Via the blood stream NPs can finally reach sensitive target sites such as lymph nodes, spleen, heart, kidney, liver, pancreas, bone marrow and brain [19,67,68,71-73]. Cell membrane penetration and particle accumulation in diverse cellular organelles (e.g. mitochondria) can finally lead to injurious responses within the crucial target organs and inflammation, immunotoxicity, cytotoxicity, genotoxicity and malignancy have been attributed to the nanoparticle-associated oxidative stress $[18,21,74-77]$. The oxidative stress resulting from the exposure to quartz and carbon black NPs can pose pronounced effects like interstitial fibrosis and airway inflammation [78-80].

\section{Conclusion}

Nanotechnology, as a strongly growing and widely applied science, has a high potential of global socioeconomic value. On one hand, the new features of designed NPs provide unprecedented technical capabilities thereby enabling them to perform absolutely novel tasks in technology and science. Unfortunately, just the same new qualities can concurrently also include undesired intrinsic features, which sometimes lead to harmful interactions with exposed organisms.

In coherence with the described alarming aspects it seems to be a high time to establish linkages between direct and indirect health impact of NP exposure and evaluate the consensus among researchers and policy makers regarding the knowledge base. The causal diagram approach has proven to be a suitable conceptualization, simplification and visualization technique that allows communication linking the scientific disciplines involved, as documented by a wide range of examples $[1,2,81,82]$. In the near future it is envisaged to use this diagram as the basis for an internet-based tool for knowledge assessment. These causal diagrams provide an important platform to identify knowledge gaps and potential agreements or disagreements on the effect of NPs on various environmental processes and their impact on human health and can contribute to sustainable governance regarding the future use of NPs.

\section{Acknowledgements}

The work has been funded by the EU FP6 coordination action HENVINET, contract no 037019. The contribution of ACG was in part made possible within NanEAU (FNR/08/SR/07 - Fonds National de la Recherche Luxembourg). MD's contribution was supported by a grant from Norway through the Norwegian Financial Mechanism in the frame of the PolishNorwegian Research Grant (PNRF-122-Al-1/07). The authors are also grateful to the reviewers for their valuable comments and suggestions and to Vanessa Peardon for her proofreading.

This article has been published as part of Environmental Health Volume 11 Supplement 1, 2012: Approaching complexities in health and environment The full contents of the supplement are available online at http://www. ehjournal.net/supplements/11/S1

\section{Author details}

${ }^{1}$ Amity University, Lucknow Campus, Viraj Khand 5, Lucknow-226010, U.P., India. ${ }^{2}$ CSIR-Indian Institute of Toxicology Research, Post Box 80, M.G. Marg, Lucknow-226001, U.P., India. ${ }^{3}$ NILU - Norwegian Institute of Air Research POB 100, 2027 Kjeller, Norway. ${ }^{4}$ Slovak Medical University, Department of Experimental and Applied Genetics, Limbova 12, 83303 Bratislava, Slovakia. ${ }^{5}$ Department of Environment and Agro-biotechnologies (EVA), Centre de Recherche Public - Gabriel Lippmann, 4422 Belvaux, Luxembourg.

\section{Authors' contributions}

SS, SKG and QR conceived and designed the review, collected the data and drafted the manuscript. $A C G, A B$ and $M D$ commented and revised the draft manuscript and contributed with some sections. AB is HENVINET project coordinator and contributor to the framework development. All authors read and revised the final version of the manuscript.

\section{Competing interests}

None declared

Published: 28 June 2012

\section{References}

1. Keune H, Gutleb AC, Zimmer KE, Ravnum S, Yang A, Bartonova A, von Krauss MK: We're only in it for the knowledge? A problem solving turn in environment and health expert elicitation. Environ Health 2012.

2. Zimmer KE, Gutleb AC, Ravnum S, Krayer von Krauss M, Murk AJ, Ropstad E, Skaare JU, Eriksen GS, Koppe J, Magnanti BL, Yang A, Bartonova A, Keune H: Policy relevant results from an expert elicitation on the health risks of phthalates. Environ Health 2012.

3. Powell MC, Kanarek MS: Nanomaterial health effects-part 1: background and current knowledge. Wisc Med J 2006, 105:16-20 [http://www. wisconsinmedicalsociety.org/_WMS/publications/wmj/pdf/105/2/16.pdf].

4. Poland CA, Duffin R, Kinloch I, Maynard A, Wallace WAH, Seaton A, Stone V, Brown S, MacNee W, Donaldson K: Carbon nanotubes introduced into the abdominal cavity of mice show asbestos like pathogenicity in a pilot study. Nat Nanotechnol 2008, 3:423-428.

5. Takagi A, Hirose A, Nishimura T, Fukumori N, Ogata A, Ohashi N, Kitajima S, Kanno J: Induction of mesothelioma in p53 +/- mouse by intraperitoneal application of multi-wall carbon nanotube. J Toxico/ $\mathrm{Sci}$ 2008, 33:105-116.

6. DEFRA: Characterizing the potential risk posed by engineered nanoparticles. Department of Environment, Food and Rural Affairs, UK; 2007, 91 [http://www.defra.gov.uk/publications/files/pb12901-nanoparticlesriskreport-071218.pdf].

7. Buzea C, Pacheco II, Robbie K: Nanomaterials and nanoparticles: Sources and toxicity. Biointerphas 2007, 2:MR17-MR71.

8. Thomas T, Bahadori T, Savage N, Thomas K: Moving Towards Exposure and Risk Evaluation of Nanomaterials: Challenges and Future Directions. Wiley Interdisc Rev - Nanomed Nanobiotechnol 2009, 1:426-433.

9. Stone V, Nowack B, Baun A, van den Brink N, Kammer F, Dusinska M, Handy R, Hankin S, Hassellöv M, Joner E, Fernandes TF: Nanomaterials for environmental studies: Classification, reference material issues, and strategies for physico-chemical characterization. Sci Total Environ 2010, 408(7):1745-1754.

10. Hund-Rinke K, Simon M: Ecotoxic effect of photocatalytic active nanoparticles $\mathrm{TiO}_{2}$ on algae and daphnids. Environ Sci Pollut Res 2006, 13:225-232. 
11. Navarro E, Baun A, Behra R, Hartmann NB, Filser J, Miao AJ, Quigg A, Santschi PH, Sigg L: Environmental behavior and ecotoxicity of engineered nanoparticles to algae, plants, and fungi. Ecotoxicol 2008, 17:372-386

12. Johnston BD, Scown TM, Moger J, Cumberland SA, Baalousha M, Linge K, van Aerle R, Jarvis K, Lead JR, Tyler CR: Bioavailability of Nanoscale Metal Oxides $\mathrm{TiO}_{2}, \mathrm{CeO}_{2}$, and $\mathrm{ZnO}$ to Fish. Environ Sci Technol 2010, 44:1144-1151.

13. Zhu S, Oberdörster $E$, Haasch ML: Toxicity of an engineered nanoparticle (fullerene, (60) in two aquatic species, Daphnia and fathead minnow. Marine Env Res 2006, 60:5-9[http://www.sciencedirect.com/science/article/ pii/S0141113606000444].

14. Zhu X, Wang J, Zhang X, Chang Y, Chen Y: Trophic transfer of $\mathrm{TiO}_{2}$ nanoparticles from daphnia to zebrafish in a simplified freshwater food chain. Chemosphere 2010, 79:928-933.

15. Handy RD, Henry TB, Scown TM, Johnston BD, Tyler CR: Manufactured nanoparticles: their uptake and effects on fish-a mechanistic analysis. Ecotoxicol 2008, 17:396-409.

16. Koelmans AA, Nowack B, Wiesner MR: Comparison of manufactured and black carbon nanoparticle concentrations in aquatic sediments. Environ Pollut 2009, 157:1110-1116.

17. Kellogg CA, Griffin DW: Aerobiology and the global transport of desert dust. Trends Ecol Evol 2006, 21:638-644.

18. Borm PJA, Robbins D, Haubold S, Kuhlbusch T, Fissan H, Donaldson K Schins R, Stone V, Kreyling W, Lademann J, Krutmann J, Warheit D, Oberdörster $\mathrm{E}$ : The potential risks of nanomaterials: a review carried out for ECETOC. Particle Fibre Toxicol 2006, 3:11.

19. Oberdörster G, Sharp Z, Atudorei V, Elder A, Gelein R, Kreyling W, Cox C Translocation of Inhaled Ultrafine Particles to the Brain. Inhal Toxicol 2004, 16:437-445.

20. NMP Expert Advisory Group (EAG): Position paper on future RTD Activities of NMP for the period 2010-2015.[http://ec.europa.eu/research/ industrial_technologies/pdf/nmp-expert-advisory-group-report_en.pdf].

21. Pacurari $\bar{M}$, Castranova $V$, Vallyathan V: Single- and multi-wall carbon nanotubes versus asbestos: are the carbon nanotubes a new health risk to humans? J Toxicol Environ Health A 2010, 73:378-95.

22. Hochella MF, Lower SK, Maurice PA, Penn RL, Sahai N, Sparks DL, Twining BS: Nanominerals, mineral nanoparticles and earth systems. Science 2008, 319:1631-1635.

23. Kulmala $M$, Kerminen VM: On the formation and growth of atmospheric nanoparticles. Atmospheric Res 2008, 90:132-150.

24. Scown TM, van Aerle R, Tyler CR: Do engineered nanoparticles pose a significant threat to the aquatic environment? Crit Rev Toxicol 2010, 40:653-670.

25. Baun A, Hartmann NB, Grieger KD, Hanse SF: Setting the limits for engineered nanoparticles in European surface waters - are current approaches appropriate? J Environ Monit 2009, 11:1774-1781.

26. Klaine SJ, Alvarez PJJ, Batley GE, Fernandes TF, Handy RD, Lyon DY, Mahendra S, MCLaughlin MJ, Lead JR: Nanomaterials in the environment: Behavior, fate, bioavailability and effects. Environ Toxicol Chem 2008, 27:1825-1851.

27. Quafoku NP: Terrestrial nanoparticles and their controls on soil/geoprocesses and reactions. Advan Agronom 2010, 107:33-91[http://www. sciencedirect.com/science/article/pii/S0065211310070021].

28. Brar SK, Verma M, Tyagi RD, Surampalli RY: Engineered nanoparticles in wastewater and wastewater sludge - evidence and impacts. Waste Man 2010, 30:504-520.

29. UNEP Assessment Report, The Asian Brown Cloud: Climate and Other Environmental Impacts. UNEP/DEWA/RS; 2002, 02-3[http://www.rrcap. unep.org/abc/impactstudy/].

30. Gustafsson O, Kruså M, Zencak Z, Sheesley RJ, Granat L, Engström E, Praveen PS, Rao PSP, Leck C, Rodhe H: Brown clouds over South Asia: biomass or fossil fuel combustion? Science 2009, 323:495.

31. Ramanathan V, Chung C, Kim D, Bettge T, Buja L, Kiehl JT, Washington WM, Fu Q, Sikka DR, Wild M: Atmospheric brown clouds: Impacts on South Asian climate and hydrological cycles. Proc Nat Acad Sci, USA 2005, 102:5326-5333.

32. Engling G, Gelencser A: Atmospheric Brown Clouds: From Local Air Pollution to Climate Change. Elements 2010, 6(4):223-228.

33. Griffin DW: Atmospheric movement of microorganisms in clouds of desert dust and implications for human health. Clin Microbiol Rev 2007, 20(3):459-77.
34. Hua NP, Kobayashi F, Iwasaka Y, Shi G, Naganuma T: Detailed identification of desert-originated bacteria carried by Asian dust storms to Japan. Aerobiologia 2007, 23(4):291-298.

35. Prinn RG, Huang J, Weiss RF, Cunnold DM, Fraser PJ, Simmonds PG, McCulloch A, Harth C, Salameh P, O'Doherty D, Wang RHJ, Porter L, Miller BR: Evidence for substantial variations of atmospheric hydroxyl radicals in the past two decades. Science 2001, 292:1882-1888.

36. Manning MR, Lowe DC, Moss RC, Bodeker GE, Allan W: Short-term variations in the oxidizing power of the atmosphere. Nature 2005 436:1001-1004.

37. Wilson SR, Solomon KR, Tang X: Changes in tropospheric composition and air quality due to stratospheric ozone depletion and climate change. Photochem Photobiol Sci 2007, 6:301.

38. Rohrer F, Berresheim $\mathrm{H}$ : Strong correlation between levels of tropospheric hydroxyl radicals and solar ultraviolet radiation. Nature 2006, 442:184-187.

39. Tromp TK, Shia RL, Allen M, Eiler JM, Yung YL: Potential environmental impact of a hydrogen economy on the stratosphere. Science 2003, 300:1740-1742.

40. Biswas P, Wu C: Nanoparticles and the environment. Air \& Waste Manage. Assoc 2005, 55:708-746[http://www.tandfonline.com/doi/abs/10.1080/ 10473289.2005.10464656]

41. Baun A, Hartmann NB, Grieger K, Kusk KO: Ecotoxicity of engineered nanoparticles to aquatic invertebrates: a brief review and recommendations for future toxicity testing. Ecotoxicol 2008, 17:387-395.

42. Holbrook RD, Murphy KE, Morrow JB, Cole KD: Trophic transfer of nanoparticles in a simplified invertebrate food web. Nature Nanotech 2008, 3:352-355.

43. Bouldin JL, Ingle TM, Sengupta A, Alexander R, Hannigan RE, Buchanan RA: Aqueous toxicity and food chain transfer of quantum dots in freshwater algae and Ceriodaphnia dubia. Environ Toxicol Chem 2008, 27:1958-1963.

44. Lin S, Reppert J, Hu Q, Hudson JS, Reid ML, Ratnikova TA, RAo AM, Luo H, Ke PC: Uptake, translocation, and transmission of carbon nanomaterials in rice plants. Small 2009, 5:1128-1132.

45. Baun A, Sørensen SN, Rasmussen RF, Hartmann NB, Koch CB: Toxicity and bioaccumulation of xenobiotic organic compounds in the presence of aqueous suspensions of aggregates of nano-C60. Aquat Toxicol 2008, 86:379-387.

46. Lin D, Xing B: Root uptake and phytotoxicity of $\mathrm{ZnO}$ nanoparticles. Environ Sci Technol 2008, 42(15):5580-5585.

47. Hischemöller A, Nordmann J, Ptacek P, Mummenhoff K, Haase M: In-vivo imaging of the uptake of upconversion nanoparticles by plant roots. $J$ Biomed Nanotechnol 2009, 5(3):278-284.

48. Cifuentes Z, Custardoy L, de la Fuente JM, Marquina C, Ibarra MR, Rubiales $D$, Pérez-de-Luque A: Absorption and translocation to the aerial part of magnetic carbon-coated nanoparticles through the root of different crop plants. J Nanobiotechnology 2010, 8:26.

49. Da Silva LC, Oliva MA, Azevedo AA, De Araujo JM: Responses of restinga plant species to pollution from an iron pelletization factory. Water Air Soil Pollut 2006, 175:241-256.

50. Canas JE, Long M, Nations S, Vadan R, Dai L, Luo M, Ambikapathi R, Lee EH, Olszyk D: Effects of functionalized and nonfunctionalized single-walled carbon nanotubes on root elongation of selected crop species. Environ Toxicol Chem 2008, 27:1922-1931.

51. Yang L, Watts DJ: Particle surface characteristics may play an important role in phytotoxicity of alumina nanoparticles. Toxicol Lett 2005, 158:122-132.

52. Nielsen HD, Berry LS, Stone V, Burridge TR, Fernandes TF: Interactions between carbon black nanoparticles and the brown algae Fucus serratus: Inhibition of fertilization and zygotic development. Nanotoxicol 2008, 2:88-89.

53. Wild $E$, Jones $\mathrm{KC}$ : Novel method for the direct visualization of in vivo nanomaterials and chemical interactions in plants. Environ Sci Technol 2009, 43:5290-5294.

54. Roh J, Sim SJ, Yi J, Park K, Chung KH, Ryu D, Choi J: Ecotoxicity of silver nanoparticles on the soil nematode Caenorhabditis elegans using functional ecotoxicogenomics. Environ Sci Technol 2009, 43:3933-3940.

55. Kruszewski M, Brzoska K, Brunborg G, Asare N, Dobrzynska M, Dusinska M, Fjellsbø L, Georgantzopoulou A, Gromadzka J, Gutleb AC, Lankoff A, Magdolenova M, Runden Pran E, Rinna A, Instanes C, Sandberg WJ, Schwarze P, Stepkowski T, Wojewódzka M, Refsnes M: Toxicity of silver 
nanomaterials in higher eukaryotes. In Advances In Molecular Toxicology. Volume 5. Elsevier;James C. Fishbein 2011:(5):179-218.

56. Scott-Fordsmand JJ, Krogh PH, Schaefer M, Johansen A: The toxicity testing of double-walled nanotubes-contaminated food to Eisenia veneta earthworms. Ecotoxicol Environ Safet 2008, 71:616-619.

57. Madl AK, Pinkerton KE: Health effects of inhaled engineered and incidental nanoparticles. Crit Rev Toxicol 2009, 39:629-658.

58. Simkó M, Mattsson MO: Risks from accidental exposures to engineered nanoparticles and neurological health effects: a critical review. Part Fibre Toxicol 2010, 7:42.

59. Pauluhn J: Comparative pulmonary response to inhaled nanostructures: considerations on test design and endpoints. Inhal Toxicol 2009, 21:40-54.

60. Hesterberg TW, Long CM, Lapin CA, Hamade AK, Valberg PA: Diesel exhaust particulate (DEP) and nanoparticle exposures: What do DEP human clinical studies tell us about potential human health hazards of nanoparticles? Inhal Toxicol 2010, 22:679-694.

61. Cassee FR, van Balen EC, Singh C, Green D, Muijser H, Weinstein J, Dreher K: Exposure, health and ecological effects review of engineered nanoscale cerium and cerium oxide associated with its use as a fuel additive. Crit Rev Toxicol 2011, 41(3):213-29.

62. Quadros ME, Marr LC: Environmental and human health risks of aerosolized silver nanoparticles. Air Waste Manag Assoc 2010, 60:770-781

63. Crosera M, Bovenzi M, Maina G, Adami G, Zanette C, Florio C, Larese FF: Nanoparticle dermal absorption and toxicity; a review of the literature. Intl. Arch Occup Environ Health 2009, 82:1043-1055.

64. Nohynek GJ, Antignac E, Re T, Toutain H: Safety assessment of personal care products/cosmetics and their ingredients. Toxicol and Appl Pharmacol 2010, 243:239-259.

65. Bouwmeester H, Dekkers S, Noordam MY, Hagens WI, Bulder AS, de Heer C, ten Voorde SECG, Wijnhoven SWP, Marvin HJP, Sips AJAM: Review of health safety aspects of nanotechnologies in food production. Regul Toxicol Pharmacol 2009, 53:52-62.

66. Nasterlack M, Zober A, Oberlinner C: Considerations on occupational medical surveillance in employees handling nanoparticles. Int Arch Occup Environ Health 2008, 81(6):721-726.

67. Nemmar A, Hoet PH, Vanquickenborne B, Dinsdale D, Thomeer M Hoylaerts MF, Vanbilloen H, Mortelmans L, Nemery B: Passage of inhaled particles into the blood circulation in humans. Circulation 2002, 105(4):411-4

68. Furuyama A, Kanno S, Kobayashi T, Hirano S: Extrapulmonary translocation of intratracheally instilled fine and ultrafine particles via direct and alveolar macrophage-associated routes. Arch Toxicol 2009, 83(5):429-37.

69. Elder A, Oberdörster G: Translocation and effects of ultrafine particles outside of the lung. Clin Occup Environ Med 2006, 5(4):785-96.

70. Radomski A, Jurasz P, Alonso-Escalano D, Drews J, Morandi M, Malinski T, Radomski MW: Nanoparticle-induced platelet aggregation and vascular thrombosis. Br J Pharmacol 2005, 146:882-893.

71. Mills L N, Amin N, Robinson D S, Anand A, Davies J, Patel D, de la Fuente M J, Cassee R F, Boon A N, Macnee W, Millar M A, Donaldson K, Newby E D: Do inhaled carbon nanoparticles translocate directly into the circulation in humans? Am J Respir Crit Care Med 2006, 173:426-431[http:// ajrccm.atsjournals.org/content/173/4/426.long].

72. Rejman J, Oberle V, Zuhorn IS, Hoekstra D: Size-dependent internalization of particles via the pathways of clathrin- and caveolae-mediated endocytosis. Biochem J 2004, 377:159-169.

73. Lockman PR, Koziara JM, Mumper RJ, Allen DD: Nanoparticle surface charges alter blood-brain barrier integrity and permeability. J Drug Target 2004, 12:635-641.

74. Kim JS, Yoon TJ, Yu KN, Kim BG, Park SJ, Kim HW, Lee KH, Park SB, Lee JK, Cho $\mathrm{MH}$ : Toxicity and tissue distribution of magnetic nanoparticles in mice. Toxicol Sci 2006, 89:338-347.

75. Pacurari M, Yin XJ, Ding M, Leonard SS, Schwegler-berry D, Ducatman BS, Chirila M, Endo M, Castranova V, Vallyathan V: Oxidative and molecular interactions of multi-wall carbon nanotubes (MWCNT) in normal and malignant human mesothelial cells. Nanotoxicol 2008, 2:155-170.

76. Jaurand MF, Renier A, Daubriac J: Mesothelioma: do asbestos and carbon nanotubes pose the same health risk? Part Fibre Toxicol 2009, 6:16.

77. Rahman Q, Lohani M, Dopp E, Pemsel H, Jonas L, Weiss DG, Schiffmann D: Evidence that ultrafine titanium dioxide induces micronuclei and apoptosis in Syrian hamster embryo fibroblasts. Environ Health Persp
2002, 110:797-800[http:/www.ncbi.nlm.nih.gov/pmc/articles/PMC1240951/? tool=pubmed].

78. Xia T, Li N, Nel AE: Potential health impact of nanoparticles. Ann Rev Pub Health 2009, 29:137-150.

79. Donaldson K, Brown D, Clouter A, Duffin R, MacNee W, Renwick L: The pulmonary toxicology of ultrafine particles. J Aerosol Med 2002, 15:213.

80. Xia T, Kovochich M, Brant J, Hotze M, Sempf J, Oberley T, Sioutas C, Yeh J, Wiesner MR, Nel AE: Comparison of the abilities of ambient and manufactured nanoparticles to induce cellular toxicity according to an oxidative stress paradigm. Nano Lett 2006, 6:1794-1807.

81. Nel A, Xia T, Mädler L, Li N: Toxic potential of materials at the nanolevel. Science 2006, 311:622-627.

82. Morgan MG, Adams PJ, Keith DW: Elicitation of expert judgments of aerosol forcing. Clim Change 2006, 75:195-214.

\section{doi:10.1186/1476-069X-11-S1-S13}

Cite this article as: Smita et al.: Nanoparticles in the environment: assessment using the causal diagram approach. Environmental Health 2012 11(Suppl 1):S13.

\section{Submit your next manuscript to BioMed Central and take full advantage of:}

- Convenient online submission

- Thorough peer review

- No space constraints or color figure charges

- Immediate publication on acceptance

- Inclusion in PubMed, CAS, Scopus and Google Scholar

- Research which is freely available for redistribution
Ciomed Central 